\title{
Contribution to the knowledge of Parajalla sanguineosignata (Spinola, 1852) (Heteroptera: Pentatomidae: Asopinae) in Patagonia
}

Contribución al conocimiento de Parajalla sanguineosignata (Spinola, 1852)

(Heteroptera: Pentatomidae: Asopinae) en Patagonia

Mariom A. Carvajal ${ }^{1,2}$, Eduardo I. Faundez ${ }^{1,2}$ \& David A. Rider ${ }^{1}$

\begin{abstract}
The nymphal instar V of Parajalla sanguineosignata (Spinola, 1852) is described. First formal records with specific locality data are given for Aysen and Magallanes Regions in Chile. San Gregorio becomes the southernmost locality known for this species.
\end{abstract}

\section{Key words:}

Hemiptera, Heteroptera, Pentatomoidea, new record, immature stages, Patagonia.

\section{Resumen}

Se describe la ninfa $V$ de Parajalla sanguineosignata (Spinola, 1852), se entregan los primeros registros formales con datos de localidad específica para las regiones de Aysén y Magallanes en Chile. San Gregorio se convierte en la localidad más meridional conocida para esta especie.

\section{Palabras clave:}

Hemiptera, Heteroptera, Pentatomoidea, nuevo registro, estados inmaduros, Patagonia.

\section{INTRODUCTION}

Pentatomidae is a family of Heteroptera which is comprised of approximately 4937 species classified in 938 genera (Faúndez et al. 2016). Within this family, the Asopinae is the fourth most diverse subfamily including 303 species classified in 63 genera (Rider et al. 2016). Members of the Asopinae are predators. Several species are economically important as biological control agents, because these feed on several pests (Schaefer \& Panizzi, 2000).
Parajalla sanguineosignata (Spinola, 1852) (Fig. 1) is a South American species of Asopinae which is widely distributed in Chile and Argentina, and is characterized by its dark purplish coloration, elongated shape and large size (Faúndez, 2010; Faúndez \& Verdejo, 2010). Although this species has a wide distributional range, little is known about its biology and immature stages. Furthermore, its southern distributional limit remains unclear. The purpose of this work is to provide new records for

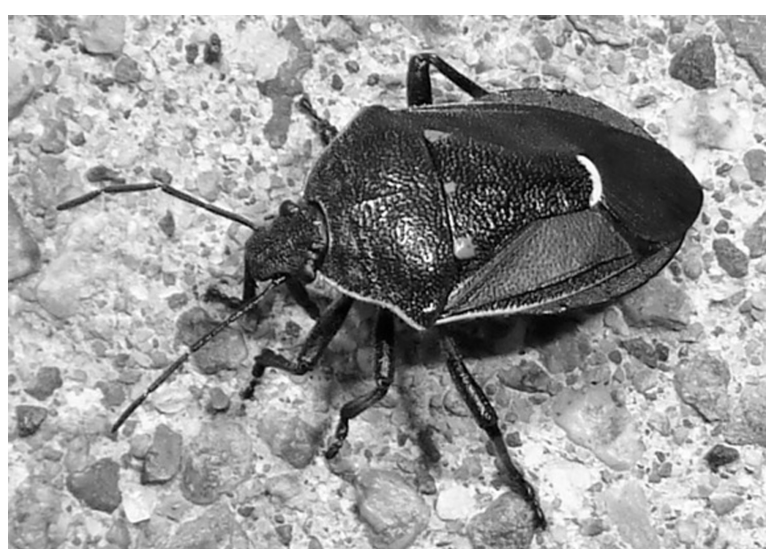

Fig. 1. Parajalla sanguineosignata (Spinola, 1852), live adult (Santa Cruz, Argentina)

1 Entomology Department, School of

Natural Resource Sciences, North Dakota State University, Dept. 7650, P.O. Box 6050; Fargo, ND, USA.

\ed.faundez@gmail.com

2 Instituto de la Patagonia, Universidad de Magallanes, Av. Bulnes 01855, Punta Arenas, Chile. 
this species in Patagonia, and to describe the $5^{\text {th }}$ instar nymph.

\section{MATERIALS AND METHODS}

In terminology and descriptive format we follow Faúndez \& Carvajal (2016). Specimens were treated on Barber's solution for cleaning and relaxing. All material examined is deposited in the Heteroptera Reference Collection of the Centro de Estudios en Biodiversidad. Measurements are in millimeters.

\section{RESULTS}

Parajalla sanguineosignata (Spinola, 1852) Description of Nymphal Instar V (Figs. 2 and 3A-C)

General body shape ovate, elongate and straightening anteriorly (Fig. 2).

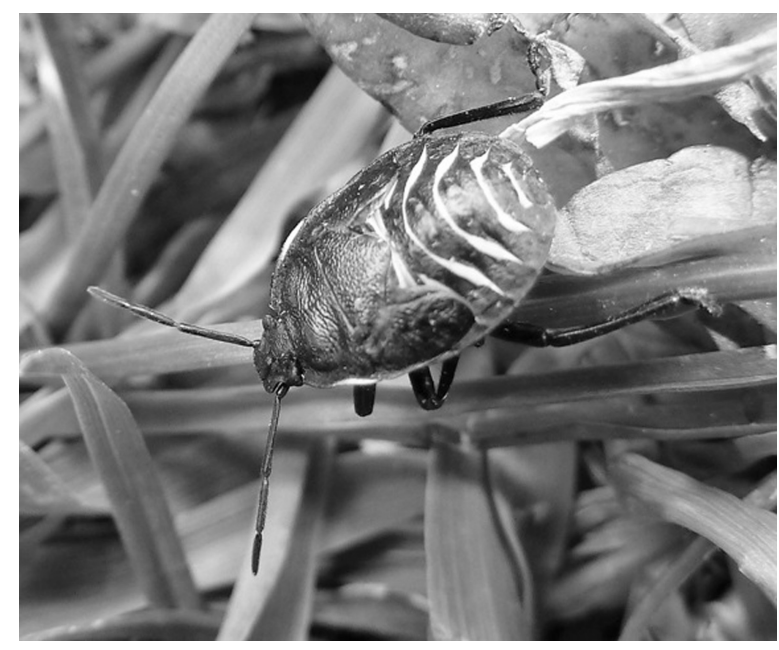

Fig. 1. Parajalla sanguineosignata (Spinola, 1852), live adult (Santa Cruz, Argentina); Fig. 2. P. sanguineosignata, live V nymph (Santa Cruz, Argentina).

Head: dark brown to black ventrally, iridescent blue dorsally, with darker punctation; shape somewhat rectangular with lateral margins concave. Paraclypei rounded apically, slightly truncate, dorsal surface with longitudinal rugae. Anteclypeus smooth, without punctation or rugae, apically truncate, subequal in length with the paraclypei. Eyes dark brown, prominent. Ocelli rounded, small, concolorous with head.
Rostrum black, surpassing procoxae. Antennae black, 4-segmented; first antennomere smallest, surpassing apex of head; second antennomere longest, not perfectly cylindrical, but flattened on internal margin (Fig. 3); third and fourth antennomeres similar in length, covered with short, light-brown hairs.

Thorax: Pronotum trapezoid, iridescent blue with yellowish lateral margins, with a sunken longitudinal middle line that extends to near apex of protoscutellum, also with two swollen spots, one on each side of longitudinal midline; in addition, irregular punctation forming rugulose lines on dorsal surface. Cicatrices opaque blue, impunctate, horizontally V-shaped. Protoscutellum wider than long, iridescent green with uniform, black punctation, and a callous spot on each basal angle. Pterothecae iridescent blue with uniform black punctation, reaching upper edge of first DAG (Fig. 2). Thoracic sternum iridescent blue, with longitudinal rugae. Legs iridescent blue covered with light-brown pilosity; tibiae sulcate on outer superior surfaces (Fig. 3B); femora flattened anteriorly, profemora each with a strong, subapical tooth (Fig. 3A); tarsi 2-segmented.

Abdomen: rounded, dorsal surface iridescent purple, with two longitudinal, thick, reddish-purple bands, and yellow transverse bands between dorsal abdominal glands (DAG) (Fig. 2). DAGs fused, placed inside rectangular iridescent blue patch (Fig. 3C). First DAG narrower than others, convex in shape (Fig. 3C); second DAG wider than first, with similar shape (Fig. 3C); third DAG widest, rectangular with rounded apices (Fig. 3C). Abdominal surface posterior of third DAG with a rectangular-shaped dark patchs present. Connexival segments blue, each with an apically bilobed, rounded, dark spots. Abdomen ventrally yellow with fine punctures and 4 rectangular, medial black spots, located in a single column. Spiracles rounded, black. Connexiva ventrally with apical edges undulated, usually with 3 irregular lobes.

Meassurements $(n=2)$. Total length: 9,63; pronotal length: 2,26; pronotal width: 5,07; head length: 1,92 ; head width: 3,72 ; pterothecae length: 2,71 ; pterothecae width: 1,89; protoscutellum length: 1,63; protoscutellum width: 3,06; maximum DAG opening width: 1,17; antennae: $\mathrm{I}=0,35 \mathrm{II}=2,11 \mathrm{III}=1,07 \mathrm{IV}=1,20$; rostrum: $\mathrm{I}=1,07$ 

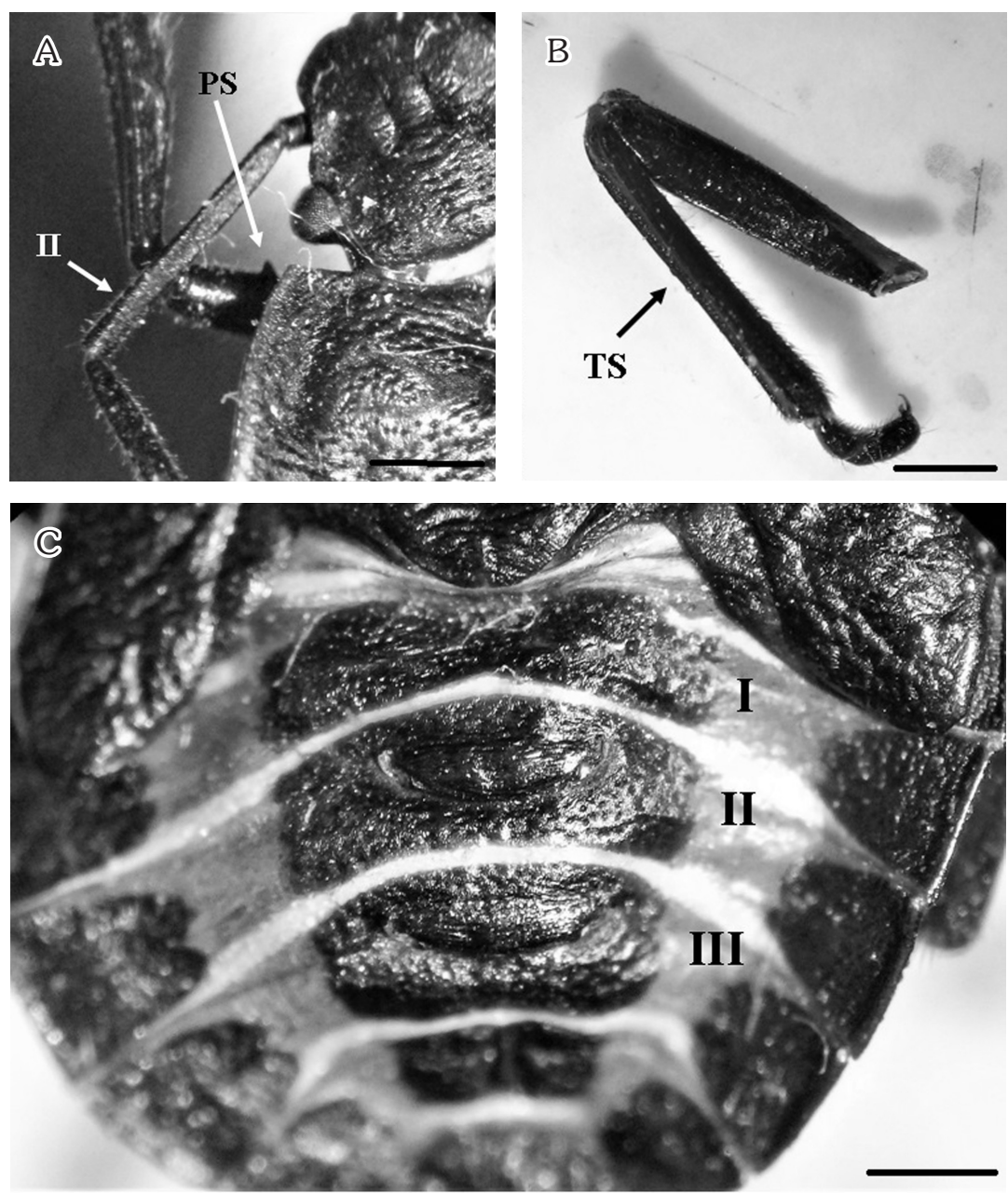

Figs. 3. Parajalla sanguineosignata (Spinola, 1852) V nymph. A. Enlarged antenna and leg, $\mathrm{PS}=$ Profemoral spine, $\mathrm{II}=$ Second antennomere; $\mathrm{B}$. Leg, $\mathrm{TS}=$ Tibial sulcus; $\mathrm{C}$.

Enlarged DAG, I= First DAG, II=Second DAG, III=Third DAG. Scale bar $=1 \mathrm{~mm}$.

II $=0,99 \mathrm{III}=0,60 \mathrm{IV}=1,07$.

Material examined: ARGENTINA: Santa

Cruz Province, Parque Nacional Los Glaciares, $50^{\circ} 0^{\prime} 0^{\prime \prime} \mathrm{S}, 73^{\circ} 14^{\prime} 58^{\prime \prime} \mathrm{W}, 2$-III-1982, 2000 $39 \% 2$ fifth instar nymphs, on steppe. A. Ashworth leg. CHILE: Aysén Region, Coihaique, Balmaceda, 4542'25'S, 71'41'33'W, 10-II-2013, 525 m s.n.m., 1 A A. Lüer leg. Magallanes Region, Tierra del Fuego, Punta Espora, 5249'S, 69 52'W II1997, 19; Parque Nacional Torres del Paine, Laguna Amarga, 5097'S, 7274'W 5-I-2004, 1 fifth instar nymph, A. Zúñiga leg.; Puerto Natales, 51 ${ }^{\circ} 73^{\prime} \mathrm{S}, \quad 72^{\circ} 49^{\prime} \mathrm{W}$, IX-1992, 19, Barrientos leg.; Bahía Posesión, 52 30 'S, 68 $95^{\prime}$ 'W 26-XI1978, 10', V. Pérez leg.; San Gregorio, 52³1’S,
6968’W, XII-1999, 10`, J. González leg.

\section{DISCUSSION AND CONCLUSIONS}

This is the first description of an immature stage for an asopine bug from Patagonia. The presence of the subapical tooth on each profemur, together with the dorsal coloration are important taxonomic characters shared with the adult; this will be helpful in telling this species apart from other pentatomoid nymphs in the area.

The southern distributional limit of this species is unclear. Grazia \& Schwertner (2008) recorded it from Tierra del Fuego, Argentina, and Faúndez \& Verdejo (2010) reported it from 
the Magallanes Region. Both papers gave the southernmost records on each country; however they did not indicate any specific locality. The citation from Argentinean Tierra del Fuego by Grazia \& Schwertner (2008) comes from a misinterpretation of Santa Cruz province in several older papers (see discussion concerning several Acanthosomatidae species in Faúndez, 2007, and Carvajal et al. 2015). However, the record provided herein from Punta Espora confirms the presence of this species in the very northern tip of the island. On the other hand, we also provide the first specific records from within the Aysén and Magallanes Regions. San Gregorio becomes the southernmost locality known for this species.

\section{ACKNOWLEDGEMENTS}

We thank all the collectors who provided material used in this study, and we also thank Flavia Raffo for the photos used in figures 1 and 2. The first author was funded by the Russell and Anna Duncan Undergraduate Research Scholars program.

\section{LITERATURE CITED}

Carvajal, M. A., Faúndez, E. I. \& Rider, D. A. (2015). Contribución al conocimiento de los Acanthosomatidae (Hemiptera: Heteroptera) de la Región de Magallanes, con descripción de una nueva especie. Anales del Instituto de la Patagonia, 43(1), 145-151.

Faúndez, E. I. (2007). Lista de las especies de Acanthosomatidae (Insecta: Hemiptera) de la región de Magallanes (Chile). Anales del Instituto de la Patagonia, 35(1), 75-78.

Faúndez, E. I. (2010). Pentatomoidea (Hemiptera: Heteroptera) wrongly labelled in Gay's
"Atlas de la Historia Física y Política de Chile" (1854). Zootaxa, 2351, 65-68.

Faúndez, E. I. \& Verdejo, L. M. (2010). La singular morfología de Acledra haematopa (Spinola, 1852) dentro del género Acledra Signoret, 1864 (Hemiptera: Heteroptera: Pentatomidae), un caso de mimetismo batesiano con descripción de un nuevo subgénero. Boletín de la Sociedad Entomológica Aragonesa, 46, 77-82.

Faúndez, E. I. \& Carvajal, M. A. (2016). Description of the 5th instar nymph of Oenopiella punctaria (Stål, 1859) (Hemiptera: Heteroptera: Pentatomidae), with new distributional records from Southern Patagonia. Zootaxa, 4067(2), 246-250.

Faúndez, E. I., Lüer, A., Cuevas-Becerra, A., Rider, D. A. \& Valdebenito, P. (2016). First record of the painted bug Bagrada hilaris (Burmeister, 1835) (Heteroptera: Pentatomidae) in South America. Arquivos Entomolóxicos, 16, 175-179.

Grazia, J. \& Schwertner, C. F. (2008). Pentatomidae e Cyrtocoridae In: Claps, L.E., Debandi, G., Roig-Juñent, S. (Eds.), Biodiversidad de Artrópodos Argentinos, vol. 2. Sociedad Entomológica Argentina, pp. 223-234.

Rider, D. A., Schwertner, C. F. \& Faúndez, E. I. (2016). The classification of the Pentatomidae (Hemiptera: Heteroptera): Past, present, and future. XXV International Congress of Entomology, ICE. Orlando, Fl., USA. doi: 10.1603/ICE.2016.94105

Schaefer, C. W. \& Panizzi, A. R. (2000). Heteroptera of Economic Importance. CRC press, Boca Raton, Florida, USA, 856 pp.

Spinola, M. (1852) Hemípteros. in: Gay, C. Historia física y política de Chile. Zoología. Vol. 7, 113-320 Paris. 